\title{
MACRO SIMULATOR (VERSION 5.0) FOR PREDICTING ATRAZINE HERBICIDE BEHAVIOR IN BRAZILIAN LATOSOLS
}

\author{
Simulador macro (versão 5.0) na predição do comportamento do herbicida \\ atrazina em latossolos brasileiros
}

\author{
Fernanda Carla Wasner Vasconcelos ${ }^{1}$, Samara Andrade Carvalho $^{2}$, Sérgio Henrique Godinho Silva ${ }^{3}$, \\ Elen Alvarenga Silva ${ }^{3}$, Mário César Guerreiro ${ }^{4}$, Nilton $\mathrm{Curi}^{3}$
}

\begin{abstract}
The knowledge of pesticides behavior is fundamental for understanding the environmental impact caused by these products. However, related field experiments are time consuming and expensive. The $\mathrm{MACRO}^{\circledR}$ simulator allows to predicting the leaching of pesticides through the soil profile and the possible environmental contamination. The objective of this work was to study the percolate behavior and the atrazine leaching in two contrasting Latosols using the $\mathrm{MACRO}^{\circledR}$ simulator. The MACRO ${ }^{\circledR}$ simulator was adequate to predict atrazine behavior under the studied conditions and it can be used for the risk evaluation of atrazine contamination in surface and underground waters.
\end{abstract}

Index terms: Pesticide, leaching, environmental impact.

\begin{abstract}
RESUMO
O conhecimento do comportamento de pesticidas é fundamental para a compreensão do impacto ambiental causado por esses produtos. No entanto, os experimentos de campo consomem tempo e investimento. O simulador MACRO ${ }^{\circledR}$ permite prever a lixiviação de pesticidas ao longo do perfil do solo e a possível contaminação ambiental. Objetivou-se, neste trabalho, estudar o comportamento do percolado e a lixiviação do herbicida atrazina em dois Latossolos contrastantes, usando o simulador MACRO ${ }^{\circledR}$. A simulação pelo $\mathrm{MACRO}^{\circledR}$ foi adequada para prever o comportamento da atrazina sob as condições estudadas e pode ser utilizada para a avaliação dos riscos de contaminação por esse herbicida em águas superficiais e profundas.
\end{abstract}

Termos para indexação: Pesticida, lixiviação, contaminação ambiental.

(Received in december 20, 2012 and approved in march 15, 2013)

\section{INTRODUCTION}

Crop management practices have assumed fundamental importance in modern agriculture which simultaneously seeks to obtain high productivity, in response to the growing demand for agricultural products, and to conserve natural resources. However, it is common to verify that productivity increases along with the detriment of environmental preservation, primarily due to inadequate soil management and massive agrochemical use. There are many cases of soil, surface and underground water contamination and damage to the animal and human health by pesticides in various countries besides Brazil. Consequently, the increasing necessity to understand pesticide dynamics in the environment and its risk evaluation under the specific conditions of the application site is evident (CASTRO et al., 2006; SILVA et al., 2009).
Atrazine(2-chloro-4-ethylamino-6-isopropylaminos-triazine) is one of the most globally used herbicides, although its use has already been prohibited in some countries. Due to its wide use and persistence in the environment, atrazine and its metabolites are frequently found in surface and underground waters (ARIASESTÉVEZet al., 2008).

The Rio das Mortes Basin, located in the center-south of the state of Minas Gerais, Brazil, includes 26 counties, with an area of $6,500 \mathrm{~km}^{2}$. In a large part of those counties, farming stands out as an important income source (OLIVEIRA JÚNIOR et al., 2008) and the use of atrazine has been mainly associated with the corn crop on Latosols (Oxisols). As in other areas of Brazil where this product is applied, studies on the occurrence of residues in soils are rare.

\footnotetext{
${ }^{1}$ Centro Universitário UNA/Campus Guajajaras - Departamento de Ciências Biológicas - Belo Horizonte - MG - Brasil

'Universidade Federal de Lavras/UFLA - Departamento de Ciência do Solo - Lavras - MG - Brasil

3Universidade Federal de Lavras/UFLA - Departamento de Ciência do Solo - Cx. P. 3037 - 37200-000 - Lavras - MG - Brasil - niltcuri@dcs.ufla.br

${ }^{4}$ Universidade Federal de Lavras/UFLA - Departamento de Química - Lavras - MG - Brasil
} 
The understanding of the pesticide transport processes in the soil can aid in the study of the factors which alter its leaching and, thus, to provide better underground water contamination predictions. According to the theories which describe the physical and chemical processes that occur in the soil, allied to numerical resolutions techniques and computational resources availability, it is possible, using simulation models, to foresee the contamination and impact risks that certain chemical components can cause to the soil-water medium (CORREIA; LANGENBACH; CAMPOS, 2010).

An example of a simulator used in the prediction of herbicide leaching is the $\mathrm{MACRO}^{\circledR}$ (version 5.0), not yet widespread in Brazil (CASTRO et al., 2006). The MACRO ${ }^{\circledR}$ is a mechanistic simulator which describes the water balance and transport in the soil profile based on global precipitation, radiation and soil data, and estimates the transport and degradation of solutes. Furthermore, the $\mathrm{MACRO}^{\circledR}$ version 5.0 can be used to simulate the transport of non-reactive tracers, such as bromide and tritium, and pesticides and their metabolites (LARSBO; JARVIS, 2003).

In this context, the objective of this work is to evaluate the efficiency of the $\mathrm{MACRO}^{\circledR}$ (version 5.0) simulator and to predict the leaching of the atrazine herbicide in Latosols, comparing them with the data obtained from the lysimeter.

\section{MATERIAL AND METHODS}

\section{Selection and identification of study areas and soil sampling}

Some Brazilian Health Surveillance Agency (ANVISA) and Ministry of Agriculture, Livestock and Food Supply databases were initially consulted to know in which crops atrazine has been applied as an active principle (SISTEMAS DE AGROTOXICOS FITOSSANITÁRIOSAGROFIT, 2010; AGÊNCIA NACIONALDE VIGILÂNCIA SANITÁRIA-ANVISA, 2010). Later, those data were correlated to those of the municipal agricultural production, supplied by the Brazilian Institute of Geography and Statistics (IBGE), to establish which of those crops occupy significant areas in the counties belonging to the Rio das Mortes Basin (Minas Gerais). This first evaluation showed that the corn crop on Latosols stands out in the region in terms of planted area and application of the product, being Bom Sucesso, Coronel Xavier Chaves, Lagoa Dourada, Ritápolis, Nazareno and Carandaí the studied counties.

Having this information, the regional EMATER (Extension Company) offices were contacted to confirm the results obtained in the databases available on the internet and to indicate the most representative corn crop areas and atrazine application history in the selected counties.

In the selected areas, mesoferric (LV1) and hypoferric (LV2) Red Latosols, which are the main soils in the region, were sampled at $0.00-0.20 \mathrm{~m}$ depth, in three different places, under sub-perennial tropical forest vegetation and gentle-undulated relief, forming two composite samples. The climate of the region is $\mathrm{Cwa}$, with rainy summer and cold and dry winter, according to Köppen classification.

\section{Samples preparation for the lysimeter modeling study}

After the sampling, a part of the soil samples was air dried, crushed and passed through a 4-mm mesh sieve for filling the lysimeter columns; the other part was passed through a 2-mm mesh sieve for physical and chemical characterization (Table1). Then, the first samples set was divided into four subsamples in which the first one (destined for filling the columns) was incubated with limestone $\left(\mathrm{CaCO}_{3}\right)$ at doses equivalent to $3.1 \mathrm{tha}^{-1}$ for LV1 and $4.6 \mathrm{tha}^{-1}$ for LV2, aiming to elevate the $\mathrm{pH}$ to 6.4 , during one month. The moisture was maintained at $60 \%$ of the pore volume for all the four subsamples. The second subsample was incubated during one month with phosphate $\left(\mathrm{KH}_{2} \mathrm{PO}_{4}\right)$ at a dose equivalent to $384.61 \mathrm{mg} \mathrm{kg}^{-1}$ for LV1 and $500 \mathrm{mg} \mathrm{kg}^{-1}$ for LV2, which correspond to half of the previously determined maximum phosphorus adsorption capacity (MPAC) (OLSEN; WATANABE, 1957). The third subsample received simultaneously liming and phosphate fertilization, and the fourth one did not receive any type of treatment (crontrol).

Table 1 - Physical attributes of the studied soils.

\begin{tabular}{ccc}
\hline \multirow{2}{*}{ Attributes } & \multicolumn{2}{c}{ Soil class } \\
\cline { 2 - 3 } & LV1 & LV2 \\
\hline Sand $\left(\mathrm{dag} \mathrm{kg}^{-1}\right)$ & 35 & 36 \\
${\text { Silt }\left(\mathrm{dag} \mathrm{kg}^{-1}\right)}^{-1}$ & 17 & 10 \\
${\text { Clay }\left(\mathrm{dag} \mathrm{kg}^{-1}\right)}$ & 48 & 54 \\
$\mathrm{BD}^{1}\left(\mathrm{~g} \mathrm{~cm}^{-3}\right)$ & 1.2 & 1.1 \\
$\mathrm{TPV}^{2}(\%)$ & 62.7 & 64.3 \\
\hline
\end{tabular}

${ }^{1}$ Bulk density; ${ }^{2}$ Total pore volume.

\section{Installation of soil columns in lysimeters and stabilization with $\mathrm{CaCl}_{2}$ solution $\left(0.01 \mathrm{~mol} \mathrm{~L}^{-1}\right)$}

After the incubation period, the samples from the two soils (approximately $30 \mathrm{~kg}$ ) were placed in 0.30 (length) 
x 0.30 (width) $\mathrm{x} 0.35$ (high) m columns. The treatments were arranged in a $2 \times 2$ factorial scheme, being tested the following factors: soils under two phosphorus conditions (with and without phosphate) and two liming conditions (with and without liming), with three replications, totaling 12 experimental plots for each soil type.

Before the application of the active principle, it was necessary to balance the ionic strength in the different treatments. For that, it was employed a $\mathrm{CaCl}_{2}$ $\left(0.01 \mathrm{~mol} \mathrm{~L}^{-1}\right)$ solution in the lysimeter columns and the ionic strength of the percolate was appraised until there was no differences among the treatments. The ionic strength was estimated from the electric conductivity, using the formula $\mathrm{I}=0.013 \mathrm{EC}$ in which $\mathrm{I}$ is the ionic strength based on the concentration expressed in $\mathrm{mol} \mathrm{L}^{-1}$ and EC corresponds to the electric conductivity expressed in $\mathrm{dS} \mathrm{m}^{-1}$, at $25^{\circ} \mathrm{C}$ (LINDSAY, 1979).

\section{Atrazine herbicide application and rainfall simulation in the lysimeter columns}

The atrazine solution was applied using a pipette ( 5 $\mathrm{mL}$ ), drop by drop, in a single dose, corresponding to approximately $27 \mathrm{mg}$ of active principle of the commercial product Gesaprim $500^{\circledR}$ (MINISTÉRIODAAGRICULTURA, PECUÁRIAE ABASTECIMENTO-MAPA, 2009) per soil column (based on previous experiments).

Twelve hours after the product application, the first rain simulation was carried out using plastic containers with perforated bottoms. The amount of simulated rain was $18.75 \mathrm{~mm}$, corresponding to the application of $1.70 \mathrm{~L}$ of deionized water in each column. That procedure was performed every three days, during 1 month, totaling the application of $187.5 \mathrm{~mm}$ of water that corresponds to the rainfall average of October and November, the main corn planting time in the region of the Rio das Mortes Basin, MG. At the product application time, as well as throughout the whole experimental period, the soil water content was maintained at field capacity. For that, the water loss by evaporation in the soil columns was controlled by daily weighting of one vase with a surface area similar to that of the soil columns, being the amount of water lost through evaporation returned to the column in the following day.

\section{Percolate collection and removal of soil from lysimeter columns}

The percolated material in each column was collected in cylindrical stainless steel containers $(2.5 \mathrm{~L})$, after each rain simulation. The total percolate volume was measured using a $2 \mathrm{~L}$ cylinder, being a $50 \mathrm{~mL}$ aliquot conserved in amber flasks at $-18^{\circ} \mathrm{C}$ for subsequent chromatographic analysis.

At the end of the leaching period, the soil contained in each column was removed in layers at depths of $0-5 ; 5-$ $10 ; 10-15 ; 15-20 ; 20-25$ and $25-30 \mathrm{~cm}$ and homogenized. A fraction of each layer was stored in plastic bags and conserved at $-18^{\circ} \mathrm{C}$ for subsequent evaluation of the atrazine concentration.

\section{Physical and chemical soil characterization}

The physical characterization of the soil samples included the particle size distribution using the pipette method (DAY, 1965). For the chemical characterization (Tables 2 and 3), the MPAC(OLSEN; WATANABE, 1957), oxide contents $\left(\mathrm{Al}_{2} \mathrm{O}_{3}\right.$ and $\left.\mathrm{Fe}_{2} \mathrm{O}_{3}\right)$ extracted by sulfuric acid digestion, $\mathrm{pH}$ in water, cation sorptive complex, available phosphorus and the total organic carbon were measured (EMPRESA BRASILEIRA DE PESQUISA AGROPECUÁRIA-EMBRAPA, 1997).

Table 2 - Sulfuric acid digestion and phosphorus adsorption for mesoferric (LV1) and hypoferric (LV2) Red Latosol from the Rio das Mortes Basin, before the treatments application.

\begin{tabular}{ccc}
\hline Characteristic & \multicolumn{2}{c}{ Soil class } \\
\hline & LV1 & LV2 \\
\cline { 2 - 3 } $\mathrm{Al}_{2} \mathrm{O}_{3}\left(\right.$ dag kg $\left.^{-1}\right)$ & 22.51 & 25.84 \\
$\mathrm{Fe}_{2} \mathrm{O}_{3}\left(\right.$ dag kg $\left.^{-1}\right)$ & 15.12 & 7.72 \\
$\mathrm{MPAC}^{1}\left(\mathrm{mg} \mathrm{dm}^{-3}\right)$ & 769 & 1000 \\
\hline
\end{tabular}

${ }^{1}$ MPAC $=$ maximum phosphorus adsorption capacity.

\section{Extraction and quantification of atrazine in soil samples and percolated water}

For the extraction of the atrazine from the soil samples at each depth of the lysimeter columns, $30 \mathrm{~g}$ of soil were used for each $30 \mathrm{~mL}$ of the extraction solution (methanol p.a.), leaving the mixture for 30 minutes on a shaking table. After the resting period for suspension decantation (approximately 20 minutes), the supernatant was collected and placed in a covered plastic flask, being this procedure performed three times. Later, the supernatant was centrifuged at 3,000 $\mathrm{rpm}$ for 10 minutes and transferred to a round bottomed flask. The solvent was evaporated at $40^{\circ} \mathrm{C}$ in a rotary evaporator under vacuum until obtaining an aliquot of approximately $5 \mathrm{~mL}$. 
Table 3 - General chemical characteristics of mesoferric (LV1) and hypoferric (LV2) Red Latosol from the Rio das Mortes Basin, before and after the treatments application.

\begin{tabular}{|c|c|c|c|c|c|c|c|c|}
\hline \multirow[t]{2}{*}{ Characteristic $^{1}$} & \multicolumn{2}{|c|}{ Control } & \multicolumn{2}{|c|}{ Liming } & \multicolumn{2}{|c|}{$\begin{array}{l}\text { Phosphate } \\
\text { Fertilization }\end{array}$} & \multicolumn{2}{|c|}{$\begin{array}{l}\text { Liming + Phosphate } \\
\text { Fertilization }\end{array}$} \\
\hline & LV1 & LV2 & LV1 & LV2 & LV1 & LV2 & LV1 & LV2 \\
\hline $\mathrm{pH}$ & 5.3 & 4.3 & 6.0 & 6.0 & 5.4 & 5.4 & 6.2 & 6.4 \\
\hline P-Mehlich $\left(\mathrm{mg} \mathrm{dm}^{-3}\right)$ & 1.3 & 1.0 & 1.9 & 0.9 & 51.2 & 54.6 & 48.8 & 46.3 \\
\hline P-resin $\left(\mathrm{mg} \mathrm{dm}^{-3}\right)$ & 3.3 & 1.0 & 3.2 & 2.8 & 133.3 & 155.2 & 115.3 & 168.8 \\
\hline P-remaining $\left(\mathrm{mg} \mathrm{dm}^{-3}\right)$ & 24.5 & 7.6 & 17.8 & 12.0 & 22.4 & 16.9 & 23.3 & 20.9 \\
\hline $\mathrm{K}^{+}\left(\mathrm{mg} \mathrm{dm}^{-3}\right)$ & 88.3 & 20.3 & 52.0 & 31.2 & 274.7 & 135.6 & 107 & 287.3 \\
\hline $\mathrm{Ca}^{2+}\left(\mathrm{cmol}_{\mathrm{c}} \mathrm{dm}^{-3}\right)$ & 2.7 & 0.4 & 4.5 & 3.0 & 3.3 & 0.5 & 4.4 & 2.9 \\
\hline $\mathrm{Mg}^{2+}\left(\mathrm{cmol}_{\mathrm{c}} \mathrm{dm}^{-3}\right)$ & 1.3 & 0.1 & 1.9 & 1.4 & 1.2 & 0.2 & 2.3 & 1.5 \\
\hline $\mathrm{SB}\left(\mathrm{cmol}_{\mathrm{c}} \mathrm{dm}^{-3}\right)$ & 4.2 & 0.6 & 6.6 & 4.5 & 5.2 & 1.1 & 6.9 & 5.1 \\
\hline $\mathrm{t}\left(\mathrm{cmol}_{\mathrm{c}} \mathrm{dm}^{-3}\right)$ & 4.5 & 1.9 & 6.6 & 4.5 & 5.4 & 1.8 & 6.9 & 5.1 \\
\hline $\mathrm{T}\left(\right.$ cmolc $\left.\mathrm{dm}^{-3}\right)$ & 9.2 & 8.6 & 9.6 & 7.4 & 10.6 & 8.1 & 10.1 & 8.3 \\
\hline $\mathrm{V}(\%)$ & 45 & 7 & 69 & 61 & 49 & 14 & 68 & 62 \\
\hline $\mathrm{Al}^{3+}\left(\mathrm{cmol}_{\mathrm{c}} \mathrm{dm}^{-3}\right)$ & 0.3 & 1.2 & 0.0 & 0.0 & 0.2 & 0.7 & 0.0 & 0.0 \\
\hline $\mathrm{m}(\%)$ & 7 & 67 & 0 & 0 & 4 & 39 & 0.0 & 0.0 \\
\hline TOC $\left(\mathrm{g} \mathrm{kg}^{-1}\right)$ & 31.0 & 21.0 & 31.0 & 22.0 & 31.0 & 21.0 & 31.0 & 21.0 \\
\hline
\end{tabular}

${ }^{1} \mathrm{SB}$ : sum of bases; $\mathrm{t}$ : effective cation exchange ${ }^{\mu}$ capacity; $\mathrm{T}$ : potential cation exchange capacity; V: bases saturation; $\mathrm{m}$ : Al saturation; TOC: total organic carbon.

The extract was filtered in a $0.22 \mu \mathrm{m}$ membrane and 1 $\mu \mathrm{L}$ was injected for 1 minute (splitless injection) in a Hewlett Packard 6890 gas chromatograph (GC), equipped with a nitrogen and phosphorus detector (NPD) and HP-5 column ( $30 \mathrm{~m} \times 320 \mu \mathrm{m} \times 0.25 \mu \mathrm{m}$ ) with 5\% phenyl-methyl-siloxane. The parameters of the operating conditions were: injector temperature $280^{\circ} \mathrm{C}$; detector temperature $300^{\circ} \mathrm{C}$; initial oven temperature $120^{\circ} \mathrm{C}$ during 1 minute; heating ramp of $50^{\circ} \mathrm{C}$ $\min ^{-1}$ up to $250^{\circ} \mathrm{C}$, remaining for 1 minute and 40 seconds. Nitrogen as $\mathrm{N}_{2}$ was used as carrier gas generating an approximate flow rate of 1.0 to $1.5 \mathrm{~mL} \mathrm{~min}^{-1}$. Standardization was achieved by means of an analytical curve with an external standard. Under those conditions, the atrazine retention time was 4 minutes and 42 seconds.

The atrazine concentration in the soil samples was quantitatively determined by comparing the heights of the peaks of the samples with those of the calibration curve (ANALYTICALMETHODS COMMITTEE, 1987), obtained by the injection of $1 \mu \mathrm{L}$ of Gesaprim $500^{\circledR}$ standard solutions, containing concentrations which varied from 31.25 to $1,000 \mu \mathrm{g} \mathrm{kg}^{-1}$.

For evaluation of the atrazine concentration in the percolated water, only the filtration of the percolate in a $0.22 \mu \mathrm{m}$ membrane was performed and $1 \mathrm{~L}$ was injected in the chromatograph under the same conditions previously described for the analysis of atrazine in the soil samples.

\section{Parameters used in the simulation}

\section{Meteorological data}

The meteorological data were collected at the Meteorological Station of the Federal University of Lavras and, later, formatted into specific files (.bin) as required by the 5.0 version of the $\mathrm{MACRO}^{\circledR}$ simulator. The required climatic variables are daily precipitation, maximum and minimum air temperature, average annual temperature, average annual thermal range, albedo and evapotranspiration.

In this context, an average annual maximum temperature of $23.2^{\circ} \mathrm{C}$, an average annual minimum temperature of $18^{\circ} \mathrm{C}$ and an albedo (reflected sunlight) equivalent to 0.1 were established; the wind speed was taken at $2 \mathrm{~m}$ of height (CASTRO et al., 2006).

\section{Lysimeter conditions and soil characteristics}

This simulation was conducted considering that in the lysimeter the leaching would happen under free drainage conditions and that there would not be a water table at its base. The soil temperature was calculated based on the heat conductivity equation developed by Jackson and Taylor (1965). 
Regarding the soil management, the soil had not been submitted to any type of preparation, it was not irrigated and there was no drain systems installed. However, for the crop, it was considered bare soil, without any type of plant covering, while for the solute, whose leaching would be simulated, the total of the original compound and the instantaneous sorption process were considered.

The soil column in all of the lysimeters was subdivided into 60 numerical compartments with a thickness determined automatically by the simulator, being the first layer established at $0.3 \mathrm{~cm}$.

\section{Parameterization, calibration and test of the MACRO $^{\circledR}$ simulator}

The input data necessary to the use of the MACRO $^{\circledR}$ simulator were obtained experimentally or compiled from the literature (ARANTES et al., 2006). For the non-available parameters, it were used the values estimated by the simulator or those suggested by the authors of the model.

The calibration of the simulator was developed from the water flow sub-model, evaluating the soil water behavior, thus defining the parameters related to this movement (VANCLOOSTER et al., 2000). Later, the solute behavior was evaluated through the pesticide transport sub-model (CASTRO et al., 2006).

\section{Data output}

For the water balance output data, the following were requested: total water content $\left(\mathrm{m}^{3} \mathrm{~m}^{-3}\right)$, accumulated precipitation $(\mathrm{mm})$ and total percolation $(\mathrm{mm})$. For the mass balance, the estimated parameters were the stored solute $\left(\mathrm{mg} \mathrm{m}^{-3}\right)$, the degradation $\left(\mathrm{mg} \mathrm{m}^{-2}\right)$ and accumulated solute in the percolate $\left(\mathrm{mg} \mathrm{m}^{-3}\right)$.

\section{RESULTS AND DISCUSSION}

\section{Estimation of soil water flow}

For the water flow estimation, files were created with the rainfall data and meteorological information. The accumulated simulated and observed precipitation values followed the same behavior and they did not present differences among the treatments. Furthermore, an overlapping of the values is observed along the period of the experiment, which demonstrates that the parameters adopted for the accumulated precipitation simulation were satisfactory.

It was possible to notice that Version 5.0 of the MACRO $^{\circledR}$ simulator presented satisfactory efficiency in the forecast of the accumulated percolate behavior during the thirty days in which the experiment was performed. This can be verified by the determination coefficient $\left(\mathrm{R}^{2}\right)$ being equal to 0.8 for LV1 and to 0.9 for LV2, resulting in an acceptable coincidence between the volume of both simulated and observed accumulated percolates, independently of the adopted fertility management practice.

It was also verified that the value of the angular coefficient of the linear regression (b1) was over 1 in both soil types, then the volume of the simulated percolate was overestimated in LV1 when submitted to the isolated liming $(\mathrm{b} 1=1.02)$ or when jointly $(\mathrm{b} 1=1.01)$ and, in LV2, when in the absence of fertility management practices $(\mathrm{b} 1=1.03)$, under isolated phosphate fertilization $(\mathrm{b} 1=1.01)$ and under liming and phosphate fertilization simultaneously $(\mathrm{b} 1=1.07)$. Furthermore, in LV1 it was verified that these values were underestimated in the control treatment $(\mathrm{b} 1=0.99)$ and under phosphate fertilization ( $\mathrm{b} 1=0.98)$. In LV2, similar behavior was observed for the liming practice $(\mathrm{b} 1=0.99)$.

In this context, it can be affirmed that the $\mathrm{MACRO}^{\circledR}$ simulator presented an adequate adjustment for the simulated percolate accumulated volumes in relation to the data obtained experimentally for LV1 and LV2 in their respective treatments and the small differences in the values were not significant.

Additionally, the parameters adopted from the literature were appropriate to calibrate the $\mathrm{MACRO}^{\circledR}$ simulator. Thus, it was possible to use the same adopted parameters in the water flow sub-model, to understand the transport of the atrazine herbicide, as proposed by Vanclooster et al. (2000).

An important parameter which allows the user to evaluate the water behavior along the soil profile is the division of the total porosity into two domains, microand macro-pores.

It was verified that the water is retained in the micro-pores and only when the soil reaches the saturation condition, the flow is directed to the macro-pores. A higher macro-pore situation in the LV1 and LV2 soil types was also observed after the application of the treatments, which can be explained by the fact that the liming and phosphate fertilization modify the chemical composition of the soil solution, slightly increasing the organic matter content, and, in consequence, interfere in the aggregation of the soil particles and in the aggregates stabilization, resulting in higher porosity (BRITO; VENDRAME; BRITO, 2005).

Experimental investigations in tropical soils which aim at understanding the water flow in the different domains which will allow validate the model with 
representative data of the environmental conditions and the tropical soils are still necessary, providing a simulation with better accuracy. As such, the use of the simulator is contingent on a previous calibration.

\section{Solute behavior}

Figures 1 and 2 show the daily behavior for atrazine along the LV1 and LV2 soil profiles estimated by the $\mathrm{MACRO}^{\circledR}$ simulator in each layer. According to these figures, there is a higher atrazine concentration in the $0-5 \mathrm{~cm}$ layer, however, with the passing of time and the application of water corresponding to the rain simulation, the conduction of the molecule to the deepest layers was observed. However, on the $30^{\text {th }}$ day of the experiment, it was noticed that atrazine remained in the $0-5$ and $5-10 \mathrm{~cm}$ of the surface layers although its concentration has been diluted in relation to the initial. This is mainly due to the transport of the molecule in the profile by leaching and, or, microbial degradation, because the improvement in the soil fertility conditions by liming practices and phosphate fertilization might have contributed to the increase of the soil microbial mass, thus elevating the degradation rate of the molecule.

In general, among the soil characteristics, those that most interfere in the movement of pesticides are texture, structure, permeability, organic matter content, water content, pHand microbial activity (SILVAet al., 2009; SILVA; VIVIAN, 2008). The particle size distribution analysis revealed sand, silt and claycontents for LV1 andLV2 of 35, 15 and 48\%, and 36, 10 and 54\%, respectively; being both included as clayey soils.

In the present study, it was observed that similar total organic carbon (TOC) values occurred in both soils (Table 3). Thus, it is possible to postulate that the high TOC content, along with the high clay content and low $\mathrm{pH}$ value (Table 3 ), contributed to the higher retention
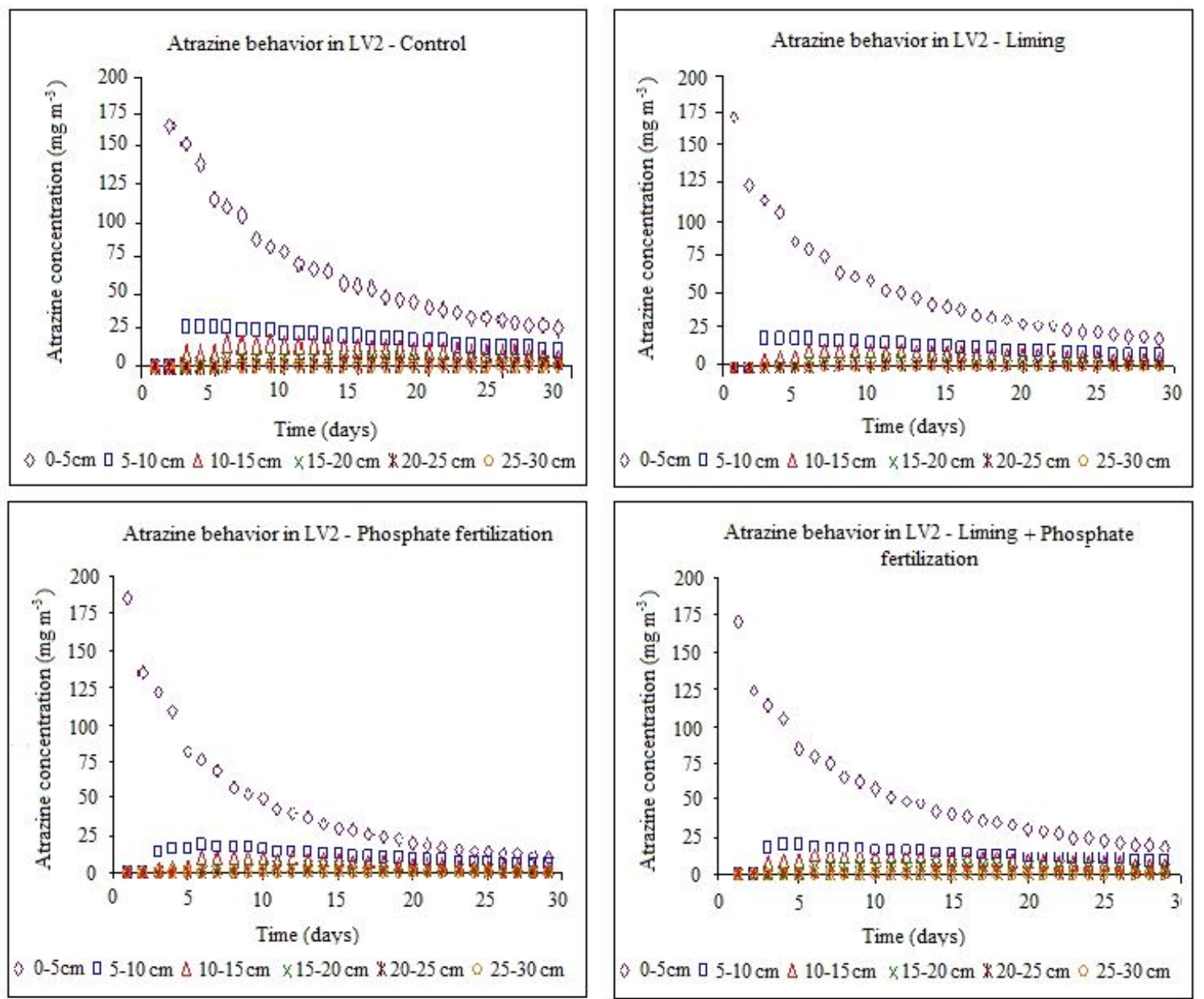

Figure 1 - Simulated atrazine behavior as function of time and along the LV1 soil profile.

Ciênc. agrotec., Lavras, v. 37, n. 3, p. 211-220, maio/jun., 2013 
and, or, molecule degradation processes, which reduced the molecule mobility along the soil profile.

In particular, the soil organic matter plays a fundamental role in the sorption of the pesticide in the soil, due to, among other aspects, its high cation exchange capacity, high specific surface area and influence on the soil microorganisms. Soils with low organic matter content possess low adsorption capacity, favoring the loss of the product by leaching (SILVA; VIVIAN, 2008).

Thus, as the atrazine concentration in the soil tends to decrease as the time between two product applications increases, as verified in the present study (Figures 1 and 2 ), the higher environmental risks due to the atrazine application in the soil occur right after its application.

The obtained and simulated results for the distribution of the herbicide in the LV1 and LV2 profiles on the $30^{\text {th }}$ day after the atrazine application are shown in figures 3 and 4 .
In general, a decrease in the atrazine concentration was observed in LV1 and in LV2 with the increase of the depth for the simulated data. The atrazine mobility was verified in the lysimeters in most of the soil columns, being considered a molecule of average mobility (SILVA et al., 2009), because the maximum depth reached was $20 \mathrm{~cm}$ in LV1 and $25 \mathrm{~cm}$ in LV2. That difference is due to the fact that LV1 presents higher TOC values, which difficulties the molecule mobility.

As shown in figure 4, the $\mathrm{MACRO}^{\circledR}$ simulator can underestimate the simulated values, which confers a margin of error in the drawing of the curve, being the largest discrepancy seen in the $5-10 \mathrm{~cm}$ layer when the soil was submitted to liming practice. As such, the most appropriate behavior for predicting atrazine concentration at the end of the 30 days is observed in LV1 (Figure 3).

Under liming and phosphate fertilization simultaneously, extremely low simulated values were
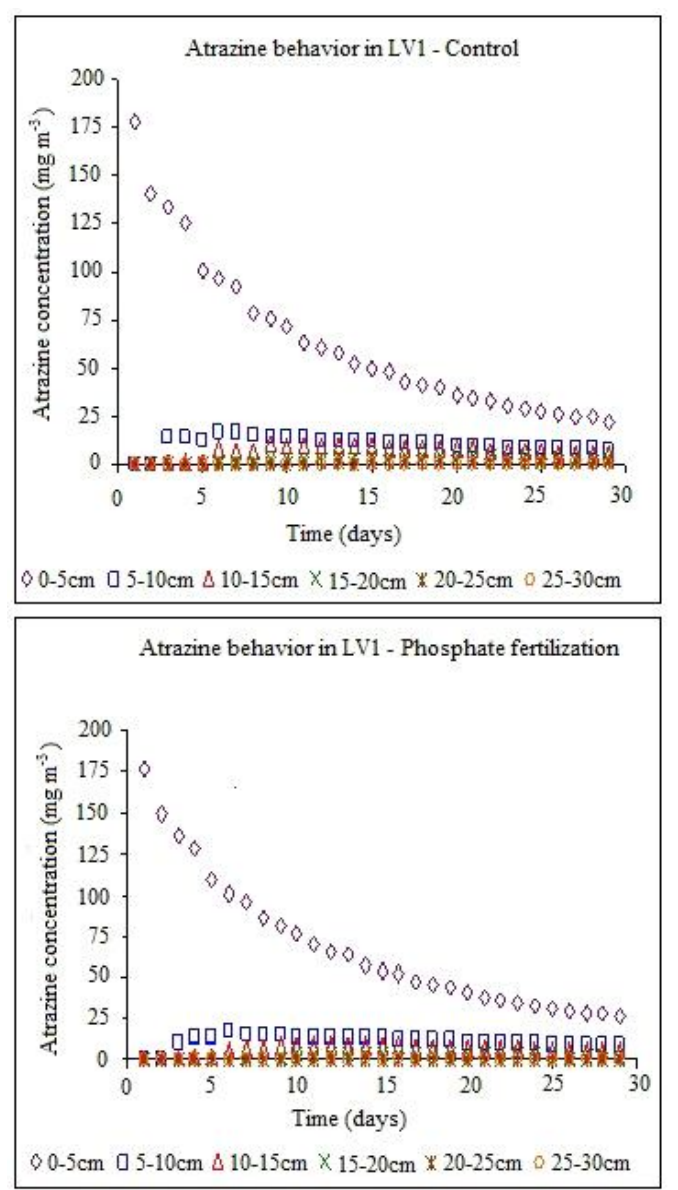
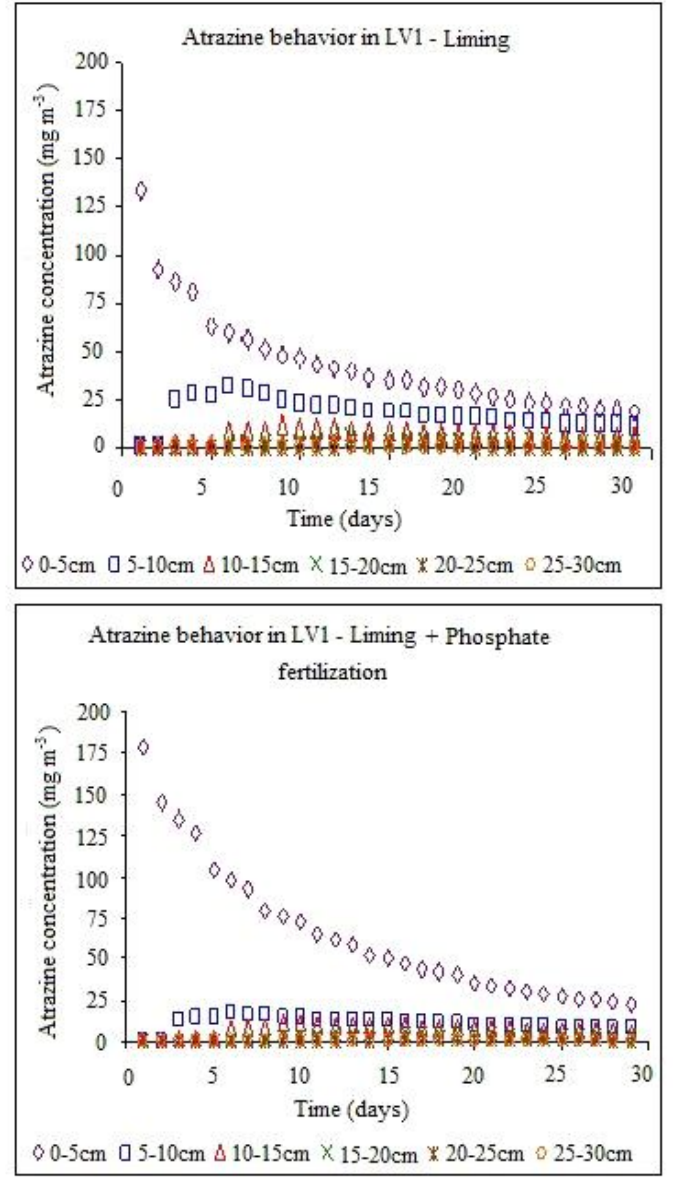

Figure 2 - Simulated atrazine behavior as function of time and along the LV2 soil profile.

Ciênc. agrotec., Lavras, v. 37, n. 3, p. 211-220, maio/jun., 2013 
verified in LV2 in the $25-30 \mathrm{~cm}$ layer, which contradicts the observed values, since the atrazine presented mobility and it was detected at a maximum depth of $25 \mathrm{~cm}$. However, in LV1 atrazine was not detected in that same layer, this result being similar to the simulated one.

Furthermore, higher homogeneity of the simulated and observed data was observed in LV1, in the $25-30 \mathrm{~cm}$ layer (Figure 3), independently of the adopted management. Similar behavior was observed in LV2, being the normalized concentration more expressive under simultaneous liming and phosphate fertilization application (Figure 4).

In general, the liming practices and phosphate fertilization, separately or not, contributed to reduce the atrazine potential mobility in the soil columns, mainly in the LV1 samples.

It is important to emphasize that the atrazine mobility was not verified beyond the $25 \mathrm{~cm}$ depth in the columns, and as a consequence, it was not possible to detect its presence in the percolated water. One of the factors that explain the absence of atrazine residues in the percolated water is the management system, which contributes to the atenuation of acidity and elevation of the nutrient content (Table 3 ), generating less restrictive conditions for the soil microbiota and, thus, probably increasing the degradation rate of the atrazine molecule (VASCONCELOS et al., 2008).
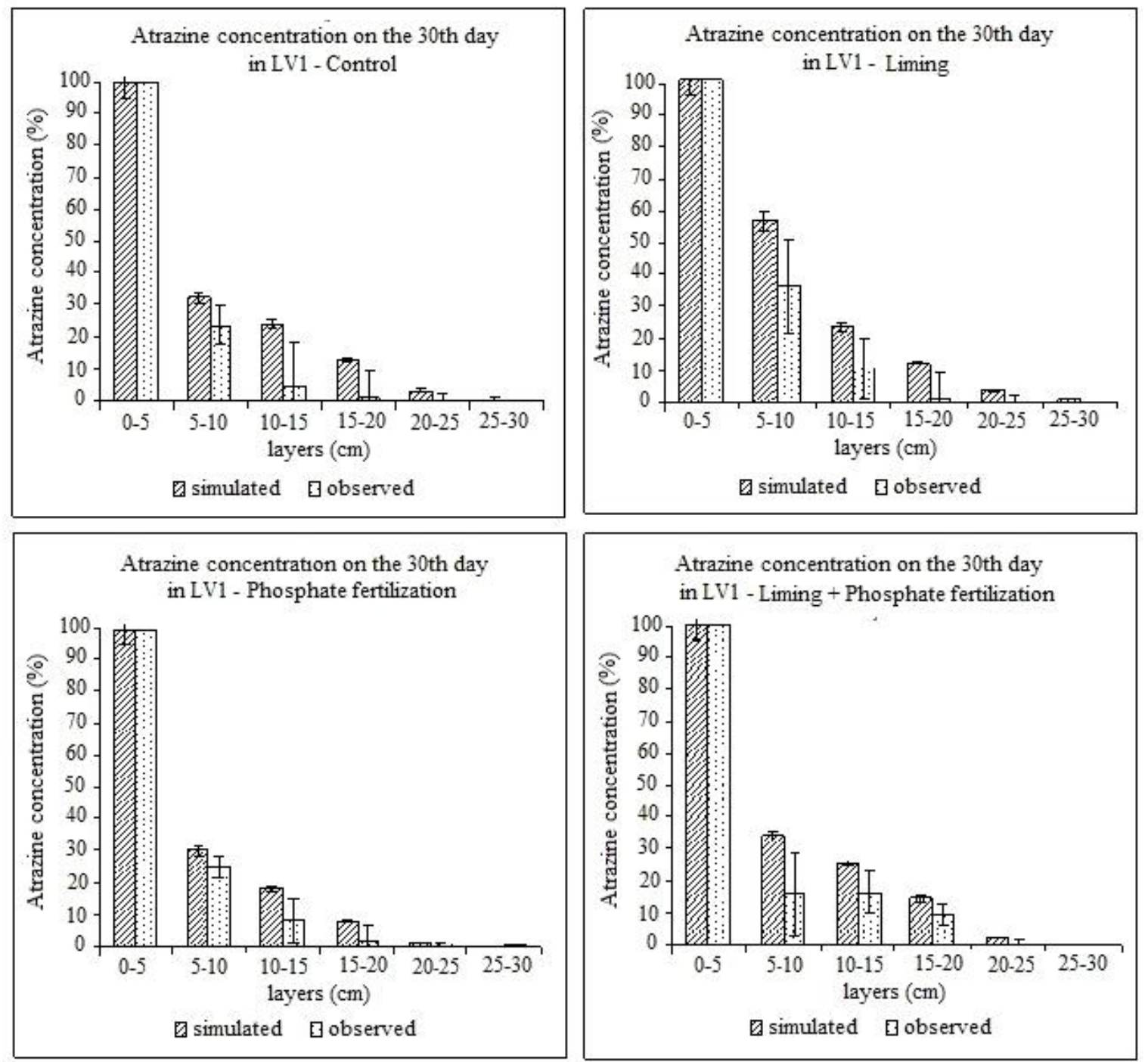

Figure 3 - Comparison between atrazine observed and simulated values in the soil column for LV1 after 30 days.

Ciênc. agrotec., Lavras, v. 37, n. 3, p. 211-220, maio/jun., 2013 

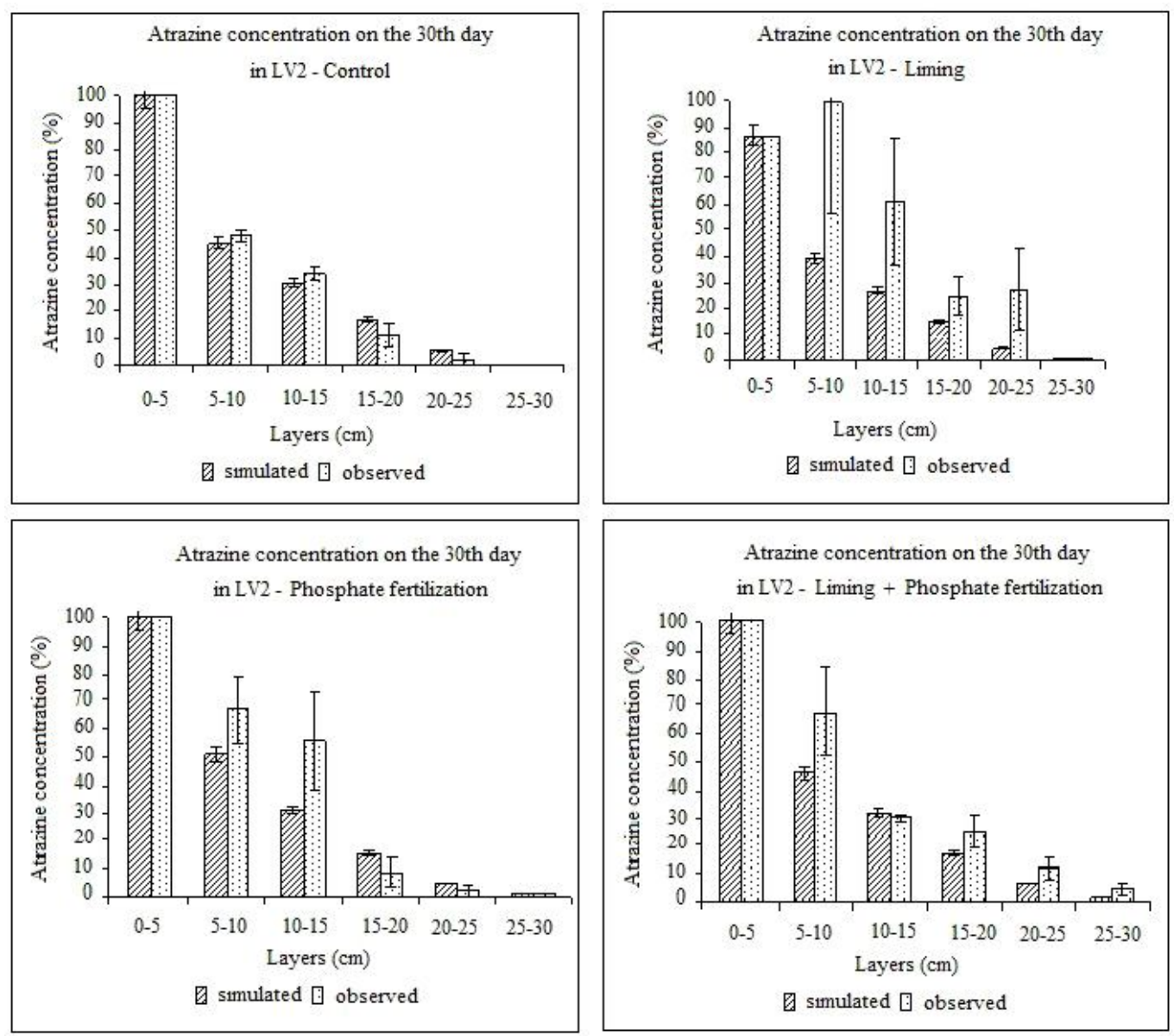

Figure 4 - Comparison between atrazine observed and simulated values in the soil column for LV2 after 30 days.

\section{CONCLUSIONS}

The performance of the $\mathrm{MACRO}^{\circledR}$ simulator in the assessment of both percolate and atrazine molecule behavior in the Latosols studied was satisfactory. Therefore, an adequate adjustment was verified between the values obtained in the lysimeters and in the simulations, demonstrating a high potential of using $\mathrm{MACRO}^{\circledR}$ as a tool for the evaluation of atrazine contamination risks in surface and underground waters, for the prevalent conditions in the Rio das Mortes Basin (MG).

\section{REFERENCES}

AGÊNCIA NACIONAL DE VIGILÂNCIA SANITÁRIAANVISA. Sistemas de informação sobre agrotóxicos. Relatório de ingrediente ativo: atrazina. Available in: <http://www.anvisa.gov.br>. Accessed on: 25 May, 2010.
SISTEMAS DE AGROTOXICOS FITOSSANITÁRIOSAGROFIT. Ingrediente ativo: atrazina. Available in: <http://extrane.agricultura.gov.br>. Accessed on: 25 May, 2010.

ANALYTICALMETHODS COMMITTEE.

Recomendations for the definition, estimation and use of detection limit. Analyst. Cambridge, n.112, p.199-204, 1987.

ARANTES, S. A et al. Sorção da atrazina em solos representativos da sub-bacia do Rio das Mortes-MG. Pesticidas: Revista de Ecotoxicologia e Meio Ambiente, Curitiba, v.16, p.101-110, 2006

ARIAS-ESTÉVEZ, M. et al. The mobility and degradation of pesticides in soils and the pollution of groundwater resources. Agriculture, Ecosystems \& Environment, Amsterdam, v.123, n.4, p.247, 2008. 
BRITO, O.R.; VENDRAME, P.R.S.; BRITO, R.M.

Alterações das propriedades químicas de um Latossolo Vermelho distroférrico submetido a tratamentos com resíduos orgânicos. Semina: Ciências Agrárias, Londrina, v.26, n.1, p.33, 2005.

CASTRO, N. R. A. et al. Avaliação do simulador MACRO $^{\circledast}$ (versão 5.0) para predição da lixiviação do inseticida tiametoxam em duas classes de solo.

Pesticidas: Revista de Ecotoxicologia e Meio Ambiente, Curitiba, v.16, p.1-12, 2006.

CORREIA, F. V.; LANGENBACH, T.; CAMPOS, T.M. Avaliação do transporte de atrazina em solos sob diferentes condições de manejo agrícola. Revista Brasileira de Ciência do Solo, Viçosa, v.34, n.2, p.525534, Mar./Abr, 2010.

DAY, P. R. Particle fractionation and particle-size analyses. In: BLACK, C. A.. (Ed.). Methods of soil analysis. American Society of Agronomy, Madison, v.1, p.545-566, 1965.

\section{EMPRESA BRASILEIRA DE PESQUISA} AGROPECUARIA-EMRAPA. Centro Nacional de Pesquisa de Solos. Manual de métodos de análises de solo. 2.ed. Rio de Janeiro: CNPS, 1997, 212p.

JACKSON, R.D.; TAYLOR, S.A. Heat transfer. In: BLACK, C. A. (ed.) Methods of soil analysis. Part 1. Phisical and mineralogical properties. Madison: American Society of Agronomy, p.349-360, 1965.

OLIVEIRA JÚNIOR, A. C. et al. Indicadores químicos de qualidade da matéria orgânica de solo da sub-bacia do Rio das Mortes sob manejos diferenciais de cafeeiro. Química Nova, São Paulo, v.31, p.1733-1737, 2008.

OLSEN, S. R.; WATANABE, F. S. A method to determine a phosphorous adsorption maximum of soils as measured by the Langmuir isotherm. Soil Science Society of America Proceedings, Madison, v.21, p.144149, 1957.

LARSBO, M.; JARVIS, N. MACRO ${ }^{\circledR}$ 5.0, a model of water flow and solute transport in macroporous soil: technical description. Swedish University of Agricultural Sciences: Emergo, Alnarp, v.1, 2003, 49p.

LINDSAY, W. L. Chemical equilibria in soils. New York: Wiley-Interscience, 1979, 447p.

MINISTÉRIODA AGRICULTURA, PECUÁRIAE ABASTECIMENTO-MAPA. Compêndio de defensivos agrícolas: Guia prático de produtos fitossanitários para uso agrícola. 8.ed. São Paulo: Organização Andrei Editora, 2009, 1380p.

SILVA, D. R. O. et al. Monitoramento de agrotóxicos em águas superficiais de regiões orizícolas no sul do Brasil. Ciência Rural, Santa Maria, v.39, n.9, p. 2383-2389, 2009

SILVA, A. A.; VIVIAN, R. Dinâmica de herbicidas no solo. In: Laércio Zambolim; Marcelo Coutinho Picanço; Antonio Alberto da silva; Lino Roberto Ferreira; Francisco Affonso Ferreira; Waldir Cintra de Jesus Junior. (Org.). Produtos Fitossanitários: Fungicidas, Inseticidas, Acaricidas e Herbicidas. 1 ed. Viçosa, MG: Suprema Gráfica e Editora Ltda, 2008, v.1, p.385-423.

VANCLOOSTER, M.et al. European test of pesticideleaching models: methodology and major recommendations. Agricultural Water Management, Elsevier Science, London, v.44, p.1-19, 2000.

VASCONCELOS, F. C. W. et al. Mobilidade do herbicida atrazina em amostras de Latossolos Vermelhos sob calagem e adubação fosfatada. Pesticidas: Revista de Ecotoxicologia e Meio Ambiente, Curitiba, v.18, p.133146, 2008. 